\title{
Should lung transplantation be performed for patients on mechanical respiratory support? The US experience
}

\author{
David P. Mason, MD, ${ }^{a}$ Lucy Thuita, MS, ${ }^{b}$ Edward R. Nowicki, MD, MS, ${ }^{a}$ Sudish C. Murthy, MD, PhD, ${ }^{a}$ \\ Gösta B. Pettersson, MD, PhD, ${ }^{\mathrm{a}}$ and Eugene H. Blackstone, $\mathrm{MD}^{\mathrm{a}, \mathrm{b}}$
}

Objective: The study objectives were to (1) compare survival after lung transplantation in patients requiring pretransplant mechanical ventilation or extracorporeal membrane oxygenation with that of patients not requiring mechanical support and (2) identify risk factors for mortality.

Methods: Data were obtained from the United Network for Organ Sharing for lung transplantation from October 1987 to January 2008. A total of 15,934 primary transplants were performed: 586 in patients on mechanical ventilation and 51 in patients on extracorporeal membrane oxygenation. Differences between nonsupport patients and those on mechanical ventilation or extracorporeal membrane oxygenation support were expressed as 2 propensity scores for use in comparing risk-adjusted survival.

Results: Unadjusted survival at 1, 6, 12, and 24 months was $83 \%, 67 \%, 62 \%$, and $57 \%$ for mechanical ventilation, respectively; $72 \%, 53 \%, 50 \%$, and $45 \%$ for extracorporeal membrane oxygenation, respectively; and $93 \%, 85 \%, 79 \%$, and $70 \%$ for unsupported patients, respectively $(P<.0001)$. Recipients on mechanical ventilation were younger, had lower forced vital capacity, and had diagnoses other than emphysema. Recipients on extracorporeal membrane oxygenation were also younger, had higher body mass index, and had diagnoses other than cystic fibrosis/bronchiectasis. Once these variables, transplant year, and propensity for mechanical support were accounted for, survival remained worse after lung transplantation for patients on mechanical ventilation and extracorporeal membrane oxygenation.

Conclusion: Although survival after lung transplantation is markedly worse when preoperative mechanical support is necessary, it is not dismal. Thus, additional risk factors for mortality should be considered when selecting patients for lung transplantation to maximize survival. Reduced survival for this high-risk population raises the important issue of balancing maximal individual patient survival against benefit to the maximum number of patients. (J Thorac Cardiovasc Surg 2010;139:765-73)

Supplemental material is available online.

Patients at the extreme of pulmonary failure who progress to respiratory failure and require respiratory support with mechanical ventilation or extracorporeal membrane oxygenation (ECMO) before lung transplantation (LTx) receive the highest priority for LTx by lung allocation score (LAS). ${ }^{1}$

\footnotetext{
From the Department of Thoracic and Cardiovascular Surgery, Heart and Vascular Institute, ${ }^{\mathrm{a}}$ and Department of Quantitative Health Sciences, Research Institute, ${ }^{\mathrm{b}}$ Cleveland Clinic, Cleveland, Ohio.

Disclosures: None.

This study was supported in part by the Peter and Elizabeth C. Tower and Family Endowed Chair in Cardiothoracic Research, James and Sharon Kennedy, the Slosburg Family Charitable Trust, and Stephen and Saundra Spencer (to G.B.P.), and by the Kenneth Gee and Paula Shaw, PhD, Chair in Heart Research (to E.H.B.).

Received for publication Jan 20, 2009; revisions received July 10, 2009; accepted for publication Sept 17, 2009; available ahead of print Nov 20, 2009.

Address for reprints: David P. Mason, MD, Cleveland Clinic, Heart and Vascular Institute, Department of Thoracic and Cardiovascular Surgery, 9500 Euclid Avenue/ Mail Stop J4-1, Cleveland, OH 44195 (E-mail: masond2@ccf.org).

$0022-5223 / \$ 36.00$

Copyright (c) 2010 by The American Association for Thoracic Surgery doi:10.1016/j.jtcvs.2009.09.031
}

However, they seem to be at high risk for early postoperative mortality and organ wastage. ${ }^{2-4}$ Few publications describe the outcomes of this debilitated group of patients, with most focusing on those with cystic fibrosis ${ }^{5-11}$; further, no single center has a large experience. Therefore, we queried the United Network for Organ Sharing registry to (1) identify factors predisposing patients to ventilatory support, (2) assess the impact of preoperative support on outcome after LTx, and (3) isolate risk factors for mortality that might help identify supported patients most likely to benefit from LTx.

\section{PATIENTS AND METHODS \\ Patients}

From October 16, 1987, to January 1, 2008, 15,934 primary lung transplants were performed in the United States. Of these, 586 patients were on mechanical ventilation and 51 patients were on ECMO at the time of transplant. Age ranged from less than 1 year to 81 years, with a mean of $38 \pm 21$ years for the mechanical ventilation group, $39 \pm 22$ years for the ECMO group, and $48 \pm 14$ years for the unsupported group. Recipient, donor, and follow-up data were obtained from the United Network for Organ Sharing database. This registry includes compulsory data required by Organ Procurement and Transplantation Network policy and is audited continuously for accuracy. 


\section{Abbreviations and Acronyms \\ $\mathrm{ECMO}=$ extracorporeal membrane oxygenation \\ LAS = lung allocation score \\ LTx = lung transplantation}

Outcome comparison. The 2 end points were retransplantation and death. Nonparametric estimates of freedom from retransplantation and survival were obtained by the Kaplan-Meier method, and parametric estimates were obtained by multiphase hazard modeling that resolved the number of phases of instantaneous risk of death (hazard function). ${ }^{16}$ (For additional details, see http://www.clevelandclinic.org/heartcenter/hazard.) Because both events were found to have an early high-risk phase and a later lower-risk phase, both unadjusted and risk-adjusted comparisons were made according to hazard phase.

Survival value of LTx for various combinations of risk factors for mortality in conjunction with mechanical ventilation or ECMO was explored by constructing nomograms from the multivariable risk factor analyses. The focus was on predicted 5-year survival according to certain risk factors, with others held constant.

\section{Data Presentation}

Continuous variables are summarized by mean \pm standard deviation except for skewed variables, which are summarized by equivalent 15 th, 50th (median), and 85th percentiles. Categoric data are summarized by frequency and percentage. All analyses were performed using SAS statistical software (SAS v9.1; SAS, Inc, Cary, NC). Survival estimates and hazard ratios are accompanied by $68 \%$ confidence limits equivalent to \pm 1 standard error.

\section{RESULTS}

\section{Factors Predisposing Patients to Ventilatory Support}

Younger patients who had poor pulmonary function, high oxygen requirement, and poor renal function, and who were considered more recently for LTx, were the most likely to receive ventilatory support, either by mechanical ventilation (Table 3) or ECMO (Table 4). These were moderately strong predictors, with C-statistics of .75 and .79, respectively. Figure 1 portrays some of these univariably. persus unsupported patients using polytomous logistic regression analysis. ${ }^{14} \mathrm{New}$ variables added to the model are listed in Appendix 1. Propensity scores were then computed for each patient for use in matching and multivariable covariate adjustment of outcomes. A greedy matching algorithm ${ }^{15}$ was used to identify 566 unsupported patient matches for the 586 mechanically ventilated patients and 49 matches for the 51 patients on ECMO. The 22 unmatched supported patients were, in general, pediatric recipients (Table E1).

TABLE 1. Lung transplant recipient and donor characteristics, details of transplantation, and in-hospital posttransplant events in ventilatorysupported and unsupported patients (categoric variables)

\begin{tabular}{|c|c|c|c|c|c|c|}
\hline \multirow[b]{2}{*}{ Variable } & \multicolumn{2}{|c|}{$\begin{array}{l}\text { Mechanical ventilation } \\
\qquad(\mathrm{n}=\mathbf{5 8 6})\end{array}$} & \multicolumn{2}{|c|}{$\begin{array}{c}\text { ECMO } \\
(\mathbf{n}=\mathbf{5 1})\end{array}$} & \multicolumn{2}{|c|}{$\begin{array}{l}\text { Unsupported } \\
(\mathrm{n}=15,297)\end{array}$} \\
\hline & n* & No. $(\%)$ & n* & No. $(\%)$ & n* & No. $(\%)$ \\
\hline \multicolumn{7}{|l|}{ Recipient } \\
\hline \multicolumn{7}{|l|}{ Demographic } \\
\hline Female & 586 & $284(48)$ & 51 & $26(51)$ & 15,297 & $7483(49)$ \\
\hline \multicolumn{7}{|l|}{ Diagnosis } \\
\hline COPD/emphysema/alpha-1 antitrypsin deficiency & 586 & $114(19)$ & 51 & $15(19)$ & 15,297 & $6960(45)$ \\
\hline Idiopathic pulmonary fibrosis & 586 & $150(26)$ & 51 & $14(27)$ & 15,297 & $3369(22)$ \\
\hline Cystic fibrosis/bronchiectasis & 586 & $166(28)$ & 51 & $6(12)$ & 15,297 & $2752(18)$ \\
\hline Sarcoidosis & 586 & $25(4.3)$ & 51 & $1(2)$ & 15,297 & $417(2.7)$ \\
\hline Pulmonary arterial hypertension & 586 & $28(4.8)$ & 51 & $5(9.8)$ & 15,297 & $731(4.8)$ \\
\hline Eisenmenger syndrome & 586 & $7(1.2)$ & 51 & $0(0)$ & 15,297 & $176(1.2)$ \\
\hline Other & 586 & $96(16)$ & 51 & $10(20)$ & 15,297 & $892(5.8)$ \\
\hline \multicolumn{7}{|l|}{ Surgical } \\
\hline Double lung transplant & 586 & $442(76)$ & 51 & $29(57)$ & 15,297 & $7481(49)$ \\
\hline \multicolumn{7}{|l|}{ Donor } \\
\hline Female & 586 & $267(46)$ & 51 & $21(41)$ & 15,297 & $5743(38)$ \\
\hline Smoker: $>20$ pack-y & 500 & $104(21)$ & 42 & $7(17)$ & 13,057 & $3200(25)$ \\
\hline
\end{tabular}

$C O P D$, Chronic obstructive pulmonary disease; $E C M O$, extracorporeal membrane oxygenation. *Patients with data available. 
TABLE 2. Lung transplant recipient and donor characteristics, details of transplantation, and in-hospital posttransplant events in ventilatorysupported and unsupported patients (continuous variables)

\begin{tabular}{|c|c|c|c|c|c|c|c|}
\hline \multirow[b]{2}{*}{ Variable } & \multicolumn{2}{|c|}{$\begin{array}{c}\text { Mechanical ventilation } \\
(\mathbf{n}=\mathbf{5 8 6})\end{array}$} & \multirow{2}{*}{\multicolumn{2}{|c|}{$\begin{array}{c}\text { ECMO } \\
(\mathrm{n}=\mathbf{5 1}) \\
\begin{array}{c}\text { Mean } \pm \text { SD or } 15 \text { th } / 50 t h \\
\text { 85th percentiles }\end{array} \\
\end{array}$}} & \multicolumn{2}{|r|}{$\begin{array}{c}\text { Unsupported } \\
(\mathrm{n}=15,297) \\
\end{array}$} & \multirow[b]{2}{*}{$P$} \\
\hline & n* & $\begin{array}{c}\text { Mean } \pm \text { SD or 15th } / 50 \text { th } / \\
\text { 85th percentiles }\end{array}$ & & & n* & $\begin{array}{c}\text { Mean } \pm \text { SD or } 15 \text { th } / 50 \text { th } / \\
\text { 85th percentiles }\end{array}$ & \\
\hline \multicolumn{8}{|l|}{ Recipient } \\
\hline \multicolumn{8}{|l|}{ Demographic } \\
\hline Age (y) & 586 & $38 \pm 21$ & 51 & $39 \pm 22$ & 15,297 & $48 \pm 14$ & $<.0001$ \\
\hline BMI $\left(\mathrm{kg} / \mathrm{m}^{2}\right)$ & 529 & $23 \pm 5.3$ & 42 & $25 \pm 4.9$ & 14,839 & $24 \pm 4.8$ & $<.0001$ \\
\hline \multicolumn{8}{|l|}{ Pulmonary function } \\
\hline $\begin{array}{l}\mathrm{O}_{2} \text { requirement at rest } \\
(\mathrm{L} / \mathrm{min})\end{array}$ & 433 & $1 / 3 / 10$ & 43 & $0 / 2.5 / 10$ & 11,843 & $0 / 2 / 4$ & $<.0001$ \\
\hline $\mathrm{FEV}_{1}(\%$ of predicted $)$ & 453 & $34 \pm 20$ & 38 & $35 \pm 21$ & 13,975 & $34 \pm 21$ & .3 \\
\hline FVC ( $\%$ of predicted $)$ & 450 & $45 \pm 17$ & 39 & $52 \pm 23$ & 13,927 & $50 \pm 18$ & $<.0001$ \\
\hline \multicolumn{8}{|l|}{ Hemodynamics } \\
\hline Cardiac output (L/min) & 266 & $5.4 \pm 1.6$ & 22 & $5.5 \pm 1.3$ & 8692 & $5.3 \pm 1.5$ & .2 \\
\hline Mean PpA (mm Hg) & 294 & $30 \pm 13$ & 23 & $32 \pm 12$ & 9234 & $28 \pm 13$ & $<.0001$ \\
\hline Creatinine (mg/dL) & 521 & $0.8 \pm 0.6$ & 44 & $1.0 \pm 0.4$ & 13,227 & $0.9 \pm 0.6$ & $<.0001$ \\
\hline LAS & 221 & $54 \pm 22$ & 16 & $54 \pm 21$ & 3302 & $40 \pm 11$ & $<.0001$ \\
\hline \multicolumn{8}{|l|}{ Surgical } \\
\hline $\begin{array}{l}\text { Maximum lung ischemic } \\
\text { time (min) }\end{array}$ & 491 & $285 \pm 120$ & 47 & $294 \pm 110$ & 13,559 & $277 \pm 100$ & .05 \\
\hline Hospital stay (d) & 404 & $11 / 26 / 66$ & 38 & $9 / 24 / 55$ & 9568 & $9 / 15 / 34$ & $<.0001$ \\
\hline \multicolumn{8}{|l|}{ Donor } \\
\hline Age $(y)$ & 585 & $30 \pm 18$ & 51 & $26 \pm 16$ & 15,289 & $31 \pm 14$ & .05 \\
\hline BMI $\left(\mathrm{kg} / \mathrm{m}^{2}\right)$ & 488 & $24 \pm 5.4$ & 42 & $25 \pm 5.1$ & 13,582 & $24 \pm 4.5$ & .03 \\
\hline
\end{tabular}

$B M I$, Body mass index; $E C M O$, extracorporeal membrane oxygenation; $F E V_{1}$, forced expiratory volume in 1 second; $F V C$, forced vital capacity; $L A S$, lung allocation score; $P P A$, pulmonary artery pressure; $S D$, standard deviation. *Patients with data available.

\section{Survival Comparison}

In addition to longer length of stay (Table 2), mechanical ventilation and ECMO were associated with reduced survival, particularly early after LTx. Unadjusted survival

TABLE 3. Factors predisposing patients to mechanical ventilation

\begin{tabular}{|c|c|c|c|}
\hline Factor & Coefficient \pm SE & $P$ & Reliability $(\%)^{*}$ \\
\hline Younger age $\dagger$ & $0.47 \pm 0.12$ & $<.0001$ & 83 \\
\hline Lower weight $\ddagger$ & $0.13 \pm 0.04$ & .0004 & 80 \\
\hline Lower FVC $(\%$ of predicted $) \S$ & $0.43 \pm 0.15$ & .01 & 60 \\
\hline $\begin{array}{l}\text { Higher oxygen requirement at } \\
\text { rest }(\mathrm{L} / \mathrm{min}) \|\end{array}$ & $0.07 \pm 0.01$ & $<.0001$ & 100 \\
\hline \multicolumn{4}{|l|}{ Creatinine $(\mathrm{mg} / \mathrm{dL})$} \\
\hline Higher creatinine 9 & $0.60 \pm 0.15$ & $<.0001$ & 89 \\
\hline Higher creatinine ${ }^{* *}$ & $0.53 \pm 0.20$ & .008 & 89 \\
\hline \multicolumn{4}{|l|}{ Date of transplant (y) } \\
\hline Later date $\dagger \dagger$ & $1.52 \pm 0.46$ & .001 & 99 \\
\hline Earlier date $\nmid \ddagger$ & $-2.09 \pm 0.70$ & .003 & 99 \\
\hline $\begin{array}{l}\text { COPD/emphysema/alpha-1 } \\
\text { antitrypsin deficiency }\end{array}$ & $-0.66 \pm 0.12$ & $<.0001$ & 99 \\
\hline \multicolumn{4}{|c|}{ 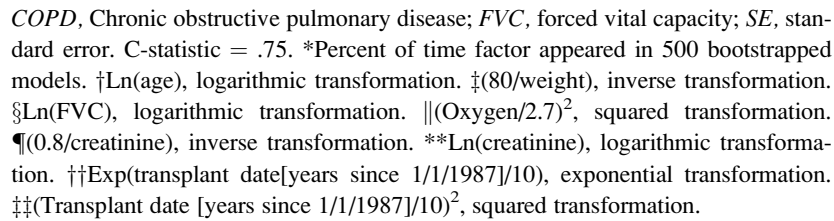 } \\
\hline
\end{tabular}

at $1,6,12$, and 24 months was $83 \%, 67 \%, 62 \%$, and $57 \%$ for mechanical ventilation, respectively; $72 \%, 53 \%$, $50 \%$, and $45 \%$ for ECMO, respectively; and $93 \%, 85 \%$, $79 \%$, and $70 \%$ for unsupported patients, respectively

TABLE 4. Factors predisposing patients to extracorporeal membrane oxygenation

\begin{tabular}{|c|c|c|c|}
\hline Factor & Coefficient \pm SE & $\boldsymbol{P}$ & Reliability $(\%)^{*}$ \\
\hline \multicolumn{4}{|l|}{ Age } \\
\hline Younger age & $-0.13 \pm 0.03$ & $<.0001$ & 98 \\
\hline Older age $\dagger$ & $2.42 \pm 1.14$ & .03 & 98 \\
\hline Higher BMI $\ddagger$ & $1.09 \pm 0.50$ & .03 & 62 \\
\hline Cystic fibrosis/bronchiectasis & $-1.30 \pm 0.51$ & .01 & 71 \\
\hline $\begin{array}{l}\text { Lower } \mathrm{FEV}_{1}(\% \text { of } \\
\text { predicted }) \S\end{array}$ & $0.87 \pm 0.23$ & .0003 & 55 \\
\hline Higher oxygen requirement $\|$ & $0.07 \pm 0.02$ & .0001 & 79 \\
\hline \multicolumn{4}{|l|}{ Creatinine } \\
\hline Lower creatinine & $0.08 \pm 0.02$ & .001 & 84 \\
\hline Higher creatinine** & $0.96 \pm 0.32$ & .003 & 84 \\
\hline $\begin{array}{l}\text { More recent } \\
\text { date of transplant } \dagger \dagger\end{array}$ & $0.35 \pm 0.08$ & $<.0001$ & 98 \\
\hline \multicolumn{4}{|c|}{$\begin{array}{l}B M I \text {, Body mass index; } F E V_{1} \text {, forced expiratory volume in } 1 \text { second; } S E \text {, standard er- } \\
\text { ror. C-statistic }=.79 . * \text { Percent of time factor appeared in } 500 \text { bootstrapped models. } \\
\dagger(\text { Age } / 50)^{2} \text {, squared transformation. } \ddagger(40 / \mathrm{BMI}) \text {, inverse transformation. } \S \mathrm{Ln}\left(\mathrm{FEV}_{1}\right) \text {, } \\
\text { logarithmic transformation. } \|(\mathrm{Oxygen} / 2.7)^{2} \text {, squared transformation. } \uparrow(0.8 / \text { creati- } \\
\text { nine })^{2} \text {, inverse squared transformation. } * * \operatorname{Ln}(\text { creatinine), logarithmic transformation. } \\
\dagger \dagger \text {. }\end{array}$} \\
\hline
\end{tabular}



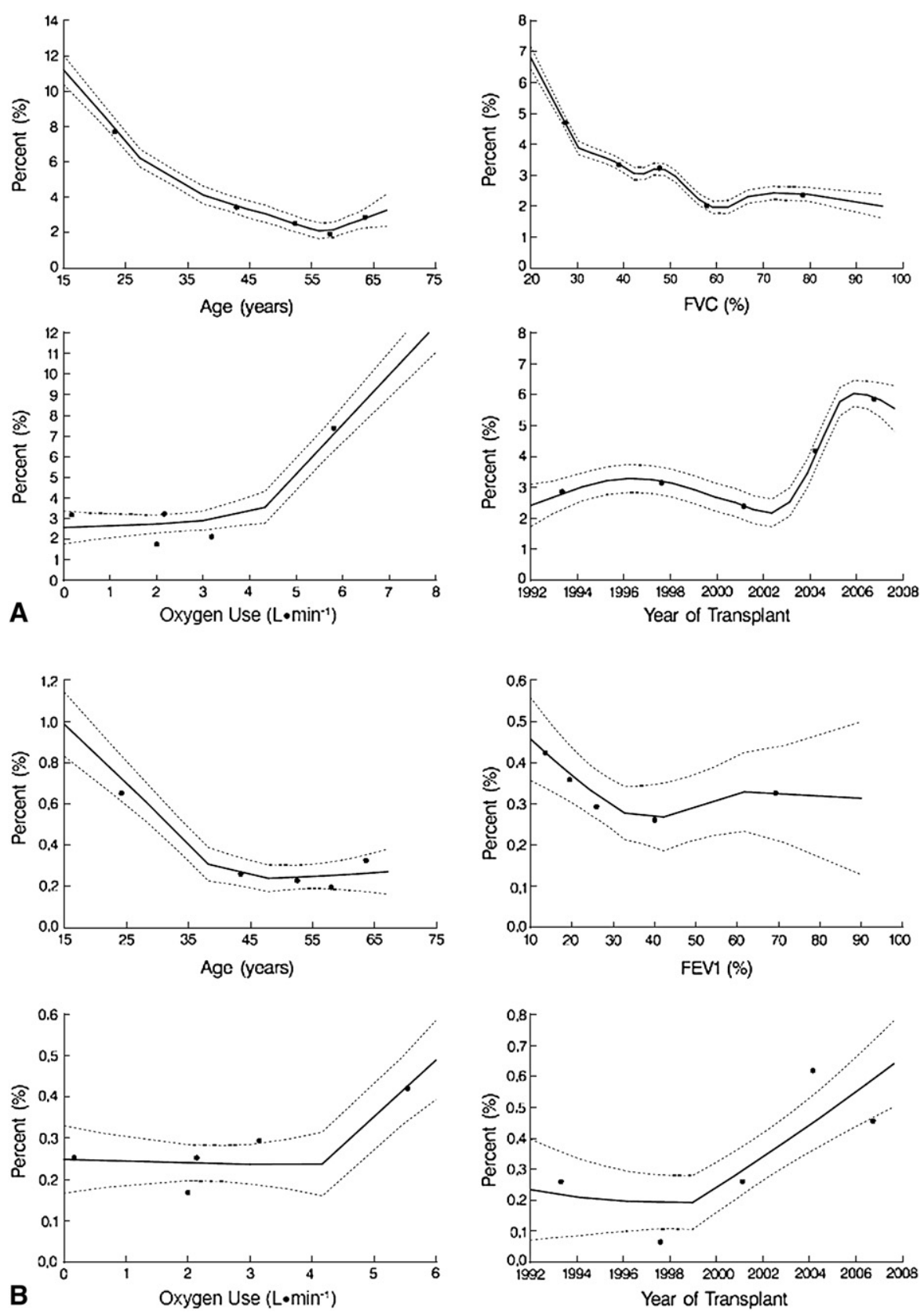

FIGURE 1. Relationship of lung transplant variables to the probability of requiring ventilatory support. Filled circles are averages within quintiles, and solid lines enclosed within $68 \%$ confidence limits show the loss estimate. A, Factors predisposing patients to mechanical ventilation. B, Factors predisposing patients to ECMO. $F V C$, forced vital capacity (expressed as percent of predicted); $F E V_{l}$, forced expiratory volume in 1 second (expressed as percent of predicted).

(Figure 2). These effects of mechanical ventilation and ECMO on survival persisted among propensity-matched patients (Figure 3). After adjustment for propensity score, the hazard ratio was $1.49(68 \%$ confidence limits, $1.39-1.58 ; P<.0001)$ for mechanically ventilated patients compared with unsupported patients in the early hazard phase and 2.55 (68\% confidence limits, 2.09-3.12; $P<$ $.0001)$ for patients on ECMO compared with unsupported patients. After the high-risk early phase, survival of patients on ECMO was similar to that of unsupported patients, with hazards converging at approximately 9 months (Figure 2, $B$ ).

\section{Risk Factors for Death}

Preoperative mechanical ventilation and ECMO were strong risk factors for mortality after LTx in the multivariable analysis (Table 5). These were additive to other risk 

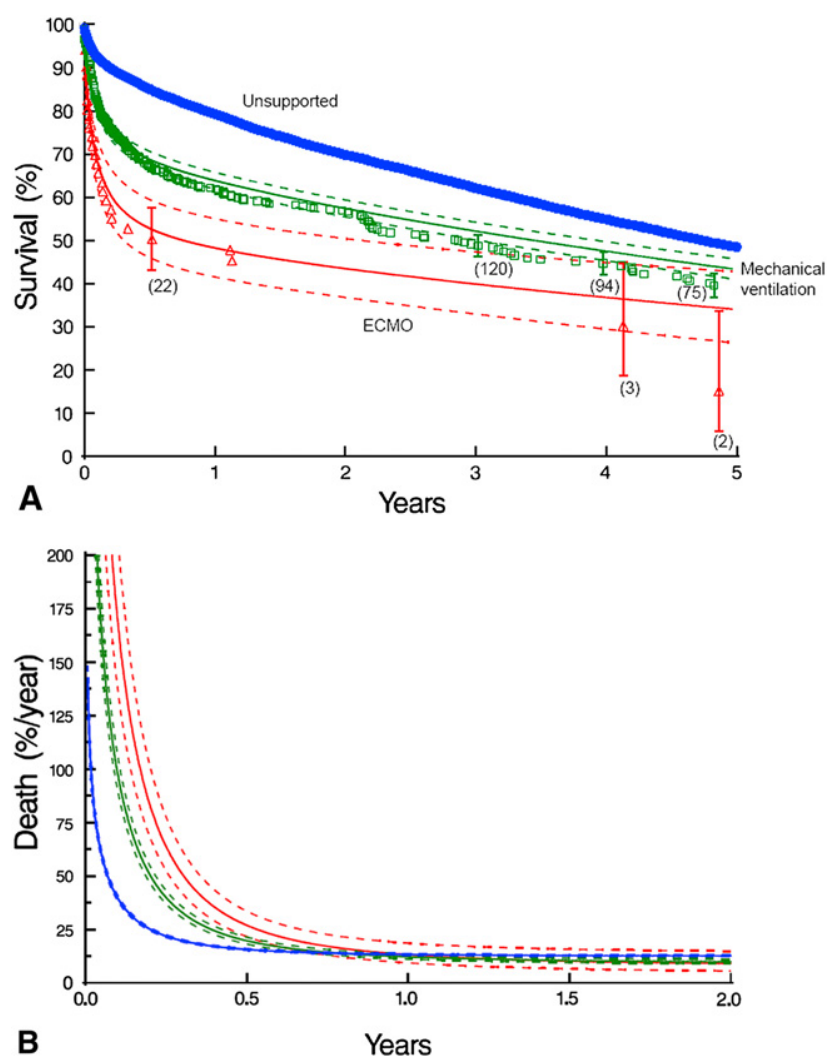

FIGURE 2. Unadjusted mortality after LTx stratified by pretransplant requirement for ventilatory support. A, Survival. Each symbol represents a death; vertical bars are $68 \%$ confidence limits representing \pm 1 standard error, and numbers in parentheses are patients remaining at risk. Solid lines are parametric estimates enclosed within dashed confidence limits. B, Hazard function (instantaneous risk) for death. Point estimates for each group are enclosed within $68 \%$ confidence limits. ECMO, Extracorporeal membrane oxygenation.

factors, including older recipient age (Figure 4), pulmonary arterial hypertension, lower pretransplant forced expiratory volume in 1 second, and longer ischemic time. There was no interaction identified between these other risk factors and mechanical ventilation or ECMO.

\section{Retransplantation Comparison}

Of 15,934 transplant recipients, 512 underwent retransplantation. There were 21,4 , and 487 retransplants in the mechanical ventilation, ECMO, and unsupported groups, respectively. In the mechanical ventilation group, the first retransplant occurred 3 days posttransplant. The first retransplant in the ECMO group was 9 days after primary transplant, and in the unsupported group, 4 patients underwent retransplantation within 1 day. Freedom from retransplant at 1 year was $97 \%, 91 \%$, and $99 \%$ for the mechanical ventilation, ECMO, and unsupported groups, respectively (ECMO, $P=.06$; mechanical ventilation, $P=$.9) (Figure 5).
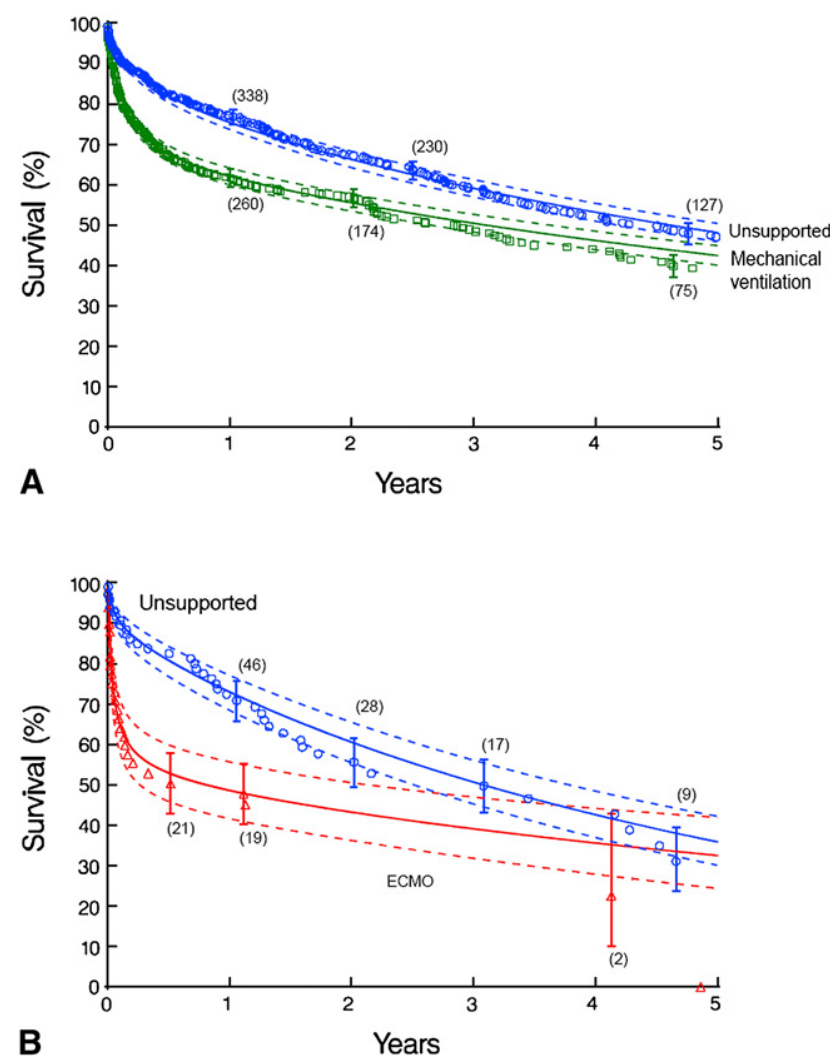

FIGURE 3. Survival for propensity-matched patients. A, Preoperative mechanical ventilation versus unsupported groups. B, ECMO versus unsupported groups. Format is as in Figure 2. ECMO, Extracorporeal membrane oxygenation.

\section{DISCUSSION}

Historically, transplant surgeons and pulmonologists have been reluctant to recommend LTx for patients on mechanical respiratory support. ${ }^{17-19}$ The prevailing sentiment was that these patients had become too sick and were no longer in the "transplant window" 20 because survival after LTx was unlikely. ${ }^{18,21}$ However, LTx has been performed selectively on supported patients and reported in a few small case series. ${ }^{11,22}$ The newly adopted LAS places a particular focus on these patients. Need for continuous mechanical ventilation is a heavily weighted factor in the LAS model (see http://www.unos.org/resources/ frm_LAS_Calculator.asp?index=98). Patients requiring mechanical support in the United States now receive the highest LAS scores and have the greatest likelihood of undergoing transplantation, in part because of this weighting. ${ }^{3}$ To better understand the outcomes of these patients, this study evaluated all patients requiring mechanical support before LTx in the United States from 1987 to 2007. LTx was uncommon for patients on mechanical ventilation and extremely rare for those on ECMO. Most patients undergoing transplantation from mechanical ventilation or ECMO underwent operation in 
TABLE 5. Incremental risk factors for death

\begin{tabular}{|c|c|c|c|}
\hline Factor & $\begin{array}{l}\text { Coefficient } \\
\quad \pm \text { SE }\end{array}$ & $\boldsymbol{P}$ & Reliability $(\%)^{*}$ \\
\hline \multicolumn{4}{|l|}{ Early hazard phase } \\
\hline \multicolumn{4}{|l|}{ Recipient } \\
\hline ECMO at transplant & $1.87 \pm 0.24$ & $<.0001$ & 78 \\
\hline ECMO propensity score $\dagger$ & $-0.12 \pm 0.05$ & .02 & \\
\hline $\begin{array}{l}\text { Mechanical ventilation } \\
\text { at transplant }\end{array}$ & $1.10 \pm 0.11$ & $<.0001$ & 100 \\
\hline $\begin{array}{l}\text { Mechanical ventilation } \\
\text { propensity score } \dagger\end{array}$ & $0.39 \pm 0.06$ & $<.0001$ & \\
\hline Older age & $0.015 \pm 0.003$ & $<.0001$ & 96 \\
\hline High weight/height ratio & $2.11 \pm 0.39$ & $<.0001$ & 98 \\
\hline $\begin{array}{l}\text { COPD/emphysema/ } \\
\text { alpha-1 antitrypsin } \\
\text { deficiency }\end{array}$ & $-0.37 \pm 0.1$ & .0002 & 100 \\
\hline $\begin{array}{l}\text { Pulmonary arterial } \\
\text { hypertension }\end{array}$ & $0.97 \pm 0.12$ & $<.0001$ & 100 \\
\hline $\begin{array}{l}\text { Cystic fibrosis/ } \\
\text { bronchiectasis }\end{array}$ & $-0.28 \pm 0.12$ & .02 & 100 \\
\hline Eisenmenger syndrome & $0.99 \pm 0.17$ & $<.0001$ & 100 \\
\hline Higher serum creatinine & $0.70 \pm 0.12$ & $<.0001$ & 100 \\
\hline $\begin{array}{l}\text { Lower serum } \\
\text { creatinine } \ddagger\end{array}$ & $-0.033 \pm 0.01$ & .0007 & 100 \\
\hline $\begin{array}{l}\text { Lower } \mathrm{FEV}_{1}(\% \text { of } \\
\text { predicted })\end{array}$ & $0.005 \pm 0.002$ & .008 & 82 \\
\hline Longer ischemic time $\S$ & $0.076 \pm 0.02$ & $<.0001$ & 97 \\
\hline Year of transplant $\|$ & $-0.38 \pm 0.04$ & $<.0001$ & 100 \\
\hline Year of transplant & $0.18 \pm 0.03$ & $<.0001$ & 100 \\
\hline \multicolumn{4}{|l|}{ Donor } \\
\hline Older age ${ }^{* *}$ & $0.095 \pm 0.02$ & $<.0001$ & 76 \\
\hline Higher weight & $0.009 \pm 0.002$ & $<.0001$ & 92 \\
\hline Non-Caucasian & $0.32 \pm 0.08$ & .01 & 99 \\
\hline Living vs cadaveric & $0.91 \pm 0.19$ & $<.0001$ & 97 \\
\hline $\begin{array}{l}\text { Head trauma as cause } \\
\text { of death }\end{array}$ & $0.23 \pm 0.07$ & .001 & 78 \\
\hline \multicolumn{4}{|l|}{ Constant hazard phase } \\
\hline \multicolumn{4}{|l|}{ Recipient } \\
\hline ECMO at transplant & $-0.39 \pm 0.60$ & .7 & 20 \\
\hline ECMO propensity score $\dagger$ & $-0.042 \pm 0.01$ & .03 & \\
\hline $\begin{array}{l}\text { Mechanical ventilation } \\
\text { at transplant }\end{array}$ & $-0.11 \pm 0.12$ & .4 & 18 \\
\hline $\begin{array}{l}\text { Mechanical ventilation } \\
\text { propensity score } \dagger\end{array}$ & $0.006 \pm 0.04$ & .9 & \\
\hline Younger age & $-0.059 \pm 0.01$ & $<.0001$ & 100 \\
\hline Older age $\dagger \dagger$ & $1.87 \pm 0.18$ & $<.0001$ & 100 \\
\hline $\begin{array}{l}\text { Greater body } \\
\text { surface area } \ddagger\end{array}$ & $0.52 \pm 0.10$ & $<.0001$ & 86 \\
\hline $\begin{array}{c}\text { Pulmonary arterial } \\
\text { hypertension }\end{array}$ & $-0.21 \pm 0.07$ & .003 & 97 \\
\hline Diabetes & $0.20 \pm 0.05$ & $<.0001$ & 94 \\
\hline Oxygen requirement $\S \S$ & $0.018 \pm 0.006$ & .001 & 98 \\
\hline Shorter ischemic time $\oint$ & $-0.039 \pm 0.01$ & .005 & 94 \\
\hline Longer ischemic time \|\| & $-0.010 \pm 0.004$ & .02 & 94 \\
\hline Single lung transplant & $0.21 \pm 0.03$ & $<.0001$ & 100 \\
\hline \multicolumn{4}{|l|}{ Donor } \\
\hline Non-Caucasian & $0.11 \pm 0.03$ & .0002 & 90 \\
\hline
\end{tabular}

TABLE 5. Continued

\begin{tabular}{|c|c|c|c|}
\hline Factor & $\begin{array}{c}\text { Coefficient } \\
\pm \mathrm{SE}\end{array}$ & $P$ & Reliability (\%)* \\
\hline Smoker: $>20$ pack-y & $0.10 \pm 0.03$ & .002 & 63 \\
\hline Diabetic & $0.29 \pm 0.08$ & .0001 & 88 \\
\hline Anti-cytomegalovirus & $0.14 \pm 0.03$ & $<.0001$ & 100 \\
\hline $\begin{array}{l}\text { Head trauma as cause } \\
\text { of death }\end{array}$ & $-0.081 \pm 0.03$ & .003 & 65 \\
\hline \multicolumn{4}{|c|}{ 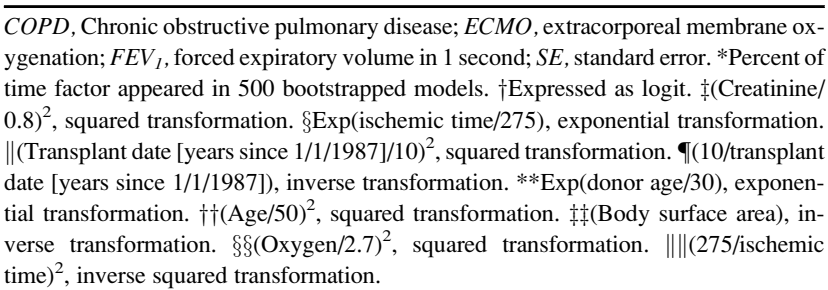 } \\
\hline
\end{tabular}

recent years; their survival was considerably worse than that of patients not requiring mechanical support.

There were notable differences in recipient and transplant characteristics between the 2 groups. The most striking was that patients undergoing LTx while on mechanical support were considerably younger, more than a decade on average. This likely reflects the bias of treating physicians for accepting higher risk and attempting more extreme therapies in younger patients. ${ }^{23}$ In addition, it might also reflect a belief that younger patients have greater functional reserve for withstanding a prolonged recovery. There were also differences in indications for LTx. Patients with emphysema were less likely and patients with cystic fibrosis were more likely to undergo transplantation from mechanical ventilation. The opposite finding held true for those on ECMO: Patients with cystic fibrosis were less likely to undergo transplantation, perhaps because of concerns over infectious complications. Patients undergoing LTx from mechanical support were more likely to undergo double LTx, although the reasons for this bias and the impact on posttransplant survival are unclear. Not surprisingly, postoperative length of stay was markedly longer for patients undergoing LTx on mechanical ventilation or ECMO than for unsupported patients.

\section{Principal Findings}

Survival. Patients supported preoperatively by mechanical ventilation or ECMO had markedly worse survival after LTx than those who did not require such support. This worse survival is not surprising. Patients requiring mechanical support before LTx are typically deconditioned from chronic progression to end-stage respiratory failure. ${ }^{24,25}$ Immobilization combined with corticosteroids causes rapid skeletal muscle wasting. ${ }^{26}$ Even brief periods of mechanical support cause diaphragmatic weakness, critical to recovery after LTx. ${ }^{27}$ Weaning from the ventilator after operation becomes more difficult, and delayed ambulation increases susceptibility to complications such as nosocomial pneumonia and thromboembolism. ${ }^{28}$ 


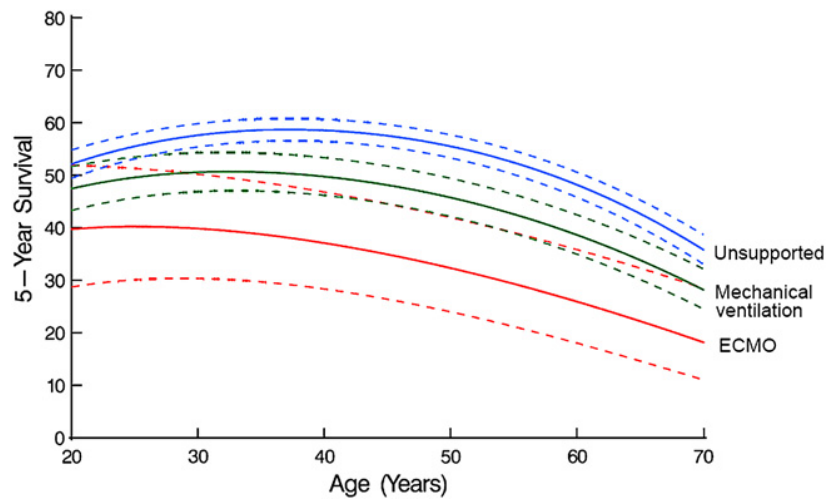

FIGURE 4. Five-year survival after LTx according to recipient age. This is a nomogram of the multivariable equation in Table 5. Except for variables depicted, values for other risk factors were set as follows: Recipient: body surface area $=1.8 \mathrm{~m}^{2}$, weight/height ratio $=0.4$, pulmonary arterial hypertension, $\mathrm{FEV}_{1}=35 \%$, oxygen requirement $=2.7(\mathrm{~L} / \mathrm{min})$, nondiabetic, creatinine $=0.89 \mathrm{mg} / \mathrm{dL}$, transplant year $=2007$. Donor: age $=30$ years, weight $=72 \mathrm{~kg}$, head trauma as cause of death, nonsmoker, nondiabetic. $E C M O$, Extracorporeal membrane oxygenation.

The increase in mortality was evident only in the early phase after LTx. Patients surviving the first 6 months had comparable long-term survival to those not requiring preoperative mechanical support. This period of elevated risk likely represents prolonged recovery from surgery. There seems to be no lasting impact on survival after this recovery phase and no long-term injury to the graft.

For patients whose underlying pulmonary disease has progressed to respiratory failure, LTx is most likely the only hope for survival. ${ }^{29}$ The LAS model was designed to balance individual waitlist urgency (likelihood of survival within 1 year without LTx) with expected posttransplant survival (likelihood of survival at 1 year after LTx). ${ }^{3}$ The results of our study support the validity of the LAS. Although survival is markedly reduced in this high-risk population, LTx is not futile.

Our study showed that patients on ECMO before LTx have the worst survival, even lower than that of patients on mechanical ventilation. Until now, there have been only a few reports on ECMO used as a "bridge to transplantation," and they have demonstrated mixed results. ${ }^{30-36}$ Currently, ECMO is not a scoring factor in the LAS. Future consideration might be given to adding preoperative ECMO support as an LAS parameter on the basis of these data. Despite high mortality, our study shows that LTx for patients on preoperative ECMO can have successful outcomes.

Risk factors for mortality. In multivariable analysis, mechanical ventilation and ECMO were strong, independent risk factors for mortality after LTx. Others, including increased recipient age, older donors, pulmonary arterial hypertension, and longer ischemic time, have been well described. ${ }^{2}$ However, there was no interaction among these

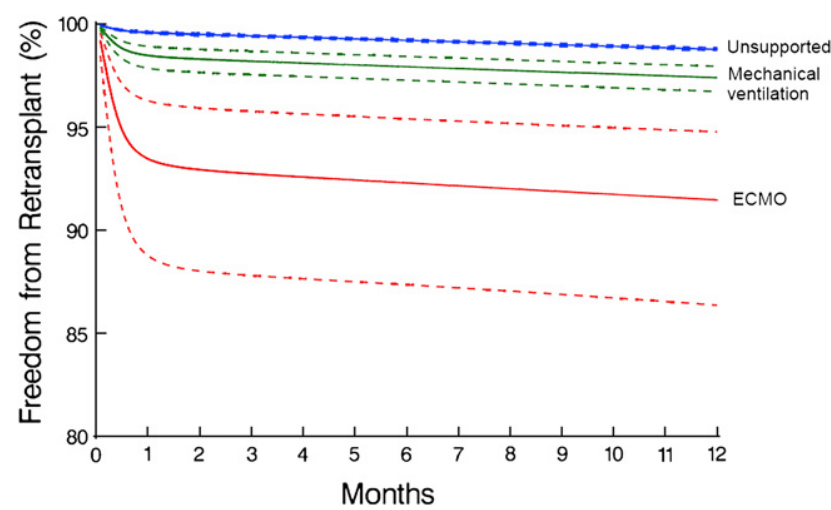

FIGURE 5. Freedom from retransplantation. ECMO, Extracorporeal membrane oxygenation.

risk factors and mechanical ventilation or ECMO. This points to a logical strategy for patient selection. Because mechanical ventilation and ECMO add important incremental risk to LTx, optimizing survival requires minimizing other known risk factors for mortality. Although some of these risk factors are modifiable, such as donor age and ischemic time, others, such as diagnosis and recipient age, are not. ${ }^{37}$ These factors must be considered before proceeding with LTx and an objective decision made about the likelihood of success.

Retransplantation. In addition to survival, retransplantation is an important outcome after LTx. Retransplantation indicates severe graft failure resulting from immune and nonimmune-mediated injury and resultant organ loss. ${ }^{38,39}$ Prevalence of retransplantation among patients requiring preoperative mechanical ventilation or ECMO was higher than among unsupported patients. Patients receiving ECMO preoperatively had the highest prevalence of retransplantation. Clearly, mediators that negatively affect survival after LTx for mechanically supported patients also negatively affect graft survival and increase need for retransplantation.

Limitations. This study has the advantage of being able to compare survival using large numbers of patients, including a wide range of donor, recipient, and transplant variables. Its limitations include lack of data collection for detailed recipient factors, some of which may be important predictors of mortality in these patients. These include signs of infection (eg, fever or elevated white blood cell count), indicators of nutritional status (eg, albumin and prealbumin), ${ }^{40,41}$ and length of pre-LTx intubation time. ${ }^{11}$ In addition, it does not consider the acute or chronic nature of respiratory decompensation or subjective factors, such as patient motivation and family support. Finally, some pretransplant patient data gathered before the LAS are difficult to compare with that gathered after the LAS, which requires continuously updated information with changes in a patient's clinical condition. 


\section{CONCLUSIONS}

Although survival after LTx is worse when preoperative mechanical support is necessary, it is not dismal. Those surviving the initial period after LTx have long-term survival comparable to those not requiring mechanical support. Reduced survival for this high-risk population raises an important ethical issue: balancing maximal individual patient survival against benefit to the maximum number of patients.

\section{References}

1. International Guidelines for the Selection of Lung Transplant Candidates. The American Society for Transplant Physicians (ASTP)/American Thoracic Society(ATS)/European Respiratory Society(ERS)/International Society for Heart and Lung Transplantation(ISHLT). Am J Respir Crit Care Med. 1998;158: 335-9.

2. Christie JD, Edwards LB, Aurora P, et al. Registry of the International Society for Heart and Lung Transplantation: twenty-fifth official adult lung and heart/lung transplantation report-2008. J Heart Lung Transplant. 2008;27: 957-69.

3. Egan TM, Murray S, Bustami RT, et al. Development of the new lung allocation system in the United States. Am J Transplant. 2006;6(5 Pt 2):1212-27.

4. Davis SQ, Garrity ER Jr. Organ allocation in lung transplant. Chest. 2007;132: 1646-51.

5. Massard G, Shennib H, Metras D, et al. Double-lung transplantation in mechanically ventilated patients with cystic fibrosis. Ann Thorac Surg. 1993;55: 1087-92.

6. Flume PA, Egan TM, Westerman JH, et al. Lung transplantation for mechanically ventilated patients. J Heart Lung Transplant. 1994;13(1 Pt 1):15-23.

7. Bartz RR, Love RB, Leverson GE, Will LR, Welter DL, Meyer KC. Pre-transplant mechanical ventilation and outcome in patients with cystic fibrosis. J Heart Lung Transplant. 2003;22:433-8.

8. Elizur A, Sweet SC, Huddleston CB, et al. Pre-transplant mechanical ventilation increases short-term morbidity and mortality in pediatric patients with cystic fibrosis. J Heart Lung Transplant. 2007;26:127-31.

9. Kotloff RM, Zuckerman JB. Lung transplantation for cystic fibrosis: special considerations. Chest. 1996;109:787-98.

10. Spahr JE, Love RB, Francois M, Radford K, Meyer KC. Lung transplantation for cystic fibrosis: current concepts and one center's experience. J Cyst Fibros. 2007; 6:334-50.

11. Baz MA, Palmer SM, Staples ED, Greer DG, Tapson VF, Davis DD. Lung transplantation after long-term mechanical ventilation: results and 1-year follow-up. Chest. 2001;119:224-7.

12. Breiman L. Bagging predictors. Machine Learning. 1996;24:123-40.

13. Rubin DB. Multiple Imputation for Non-response in Surveys. New York: Wiley; 1997.

14. Blackstone EH. Comparing apples and oranges. J Thorac Cardiovasc Surg. 2002; 123:8-15.

15. Bergstralh EJ, Konsanke JL. Computerized Matching of Cases to Controls. Technical report No. 56. Department of Health Science Research. Rochester, MN: Mayo Clinic; 1995.

16. Blackstone EH, Naftel DC, Turner ME Jr. The decomposition of time-varying hazard into phases, each incorporating a separate stream of concomitant information. J Am Stat Assoc. 1986;81:615-24.

17. Veith FJ. Lung transplantation. Transplant Proc. 1977;9:203-8.

18. Smits JM, Mertens BJ, Van Houwelingen HC, Haverich A, Persijn GG, Laufer G. Predictors of lung transplant survival in eurotransplant. Am J Transplant. 2003;3: 1400-6.
19. Maurer JR, Frost AE, Estenne M, Higenbottam T, Glanville AR. International guidelines for the selection of lung transplant candidates. The International Society for Heart and Lung Transplantation, the American Thoracic Society, the American Society of Transplant Physicians, the European Respiratory Society. Transplantation. 1998;66:951-6.

20. Kadikar A, Maurer J, Kesten S. The six-minute walk test: a guide to assessment for lung transplantation. J Heart Lung Transplant. 1997;16:313-9.

21. O'Brien G, Criner GJ. Mechanical ventilation as a bridge to lung transplantation. J Heart Lung Transplant. 1999;18:255-65.

22. Low DE, Trulock EP, Kaiser LR, et al. Lung transplantation of ventilator-dependent patients. The Washington University Lung Transplantation Group. Chest. 1992;101:8-11.

23. Wells A, Faro A. Special considerations in pediatric lung transplantation. Semin Respir Crit Care Med. 2006;27:552-60.

24. Wust RC, Degens H. Factors contributing to muscle wasting and dysfunction in COPD patients. Int J Chron Obstruct Pulm dis. 2007;2:289-300.

25. Enright S, Chatham K, Ionescu AA, Unnithan VB, Shale DJ. The influence of body composition on respiratory muscle, lung function and diaphragm thickness in adults with cystic fibrosis. J Cyst Fibros. 2007;6:384-90.

26. Gruther W, Benesch T, Zorn C, et al. Muscle wasting in intensive care patients: ultrasound observation of the M. quadriceps femoris muscle layer. $J$ Rehabil Med. 2008;40:185-9.

27. Vassilakopoulos T, Petrof BJ. Ventilator-induced diaphragmatic dysfunction. Am J Respir Crit Care Med. 2004;169:336-41.

28. Schweickert WD, Hall J. ICU-acquired weakness. Chest. 2007;131:1541-9.

29. Spicher JE, White DP. Outcome and function following prolonged mechanical ventilation. Arch Intern Med. 1987;147:421-5.

30. Pereszlenyi A, Lang G, Steltzer H, et al. Bilateral lung transplantation with intraand postoperatively prolonged ECMO support in patients with pulmonary hypertension. Eur J Cardiothorac Surg. 2002;21:858-63.

31. Aigner C, Wisser W, Taghavi S, et al. Institutional experience with extracorporeal membrane oxygenation in lung transplantation. Eur J Cardiothorac Surg. 2007; 31:468-74.

32. Jackson A, Cropper J, Pye R, Junius F, Malouf M, Glanville A. Use of extracorporeal membrane oxygenation as a bridge to primary lung transplant: 3 consecutive, successful cases and a review of the literature. J Heart Lung Transplant. 2008;27:348-52.

33. Fischer S, Hoeper MM, Bein T, et al. Interventional lung assist: a new concept of protective ventilation in bridge to lung transplantation. Asaio J. 2008; 54:3-10.

34. Fischer S, Simon AR, Welte T, et al. Bridge to lung transplantation with the novel pumpless interventional lung assist device NovaLung. J Thorac Cardiovasc Surg. 2006;131:719-23.

35. Broome M, Palmer K, Schersten H, Frenckner B, Nilsson F. Prolonged extracorporeal membrane oxygenation and circulatory support as bridge to lung transplant. Ann Thorac Surg. 2008;86:1357-60.

36. Fischer S, Hoeper MM, Tomaszek S, et al. Bridge to lung transplantation with the extracorporeal membrane ventilator Novalung in the veno-venous mode: the initial Hannover experience. Asaio J. 2007;53:168-70.

37. Christie JD. Lung allograft ischemic time: crossing the threshold. Am J Respir Crit Care Med. 2005;171:673-4.

38. Magee JC, Barr ML, Basadonna GP, et al. Repeat organ transplantation in the United States, 1996-2005. Am J Transplant. 2007;7(5 Pt 2):1424-33.

39. Martinu T, Howell DN, Davis RD, Steele MP, Palmer SM. Pathologic correlates of bronchiolitis obliterans syndrome in pulmonary retransplant recipients. Chest. 2006;129:1016-23.

40. Gonzalez-Castro A, Llorca J, Suberviola B, Diaz-Reganon G, Ordonez J, Minambres E. Influence of nutritional status in lung transplant recipients. Transplant Proc. 2006;38:2539-40.

41. Madill J, Gutierrez C, Grossman J, et al. Nutritional assessment of the lung transplant patient: body mass index as a predictor of 90-day mortality following transplantation. J Heart Lung Transplant. 2001;20:288-96. 


\section{APPENDIX 1. Variables considered in analyses}

\section{Recipient}

Demographics:

Age $(\mathrm{y})$, weight $(\mathrm{kg})$, height $(\mathrm{cm})$, weight/height ratio, body surface area $\left(\mathrm{m}^{2}\right)$, body mass index $\left(\mathrm{kg} / \mathrm{m}^{2}\right)$, gender, race

Diagnosis:

Idiopathic pulmonary fibrosis, chronic obstructive pulmonary disease/emphysema + alpha-antitrypsin deficiency, primary arterial hypertension Eisenmenger syndrome, sarcoidosis, cystic fibrosis + bronchiectasis

Lung function:

$\mathrm{FEV}_{1} \%$ of predicted, FVC $\%$ of predicted

Support:

Oxygen requirement, mechanical ventilation, ECMO

Comorbidities:

Diabetes, smoking history, drug-treated hypertension, creatinine

Serology:

ABO blood groups, panel-reactive antibodies

\section{Donor}

Demographics:

Age $(\mathrm{y})$, body mass index $\left(\mathrm{kg} / \mathrm{m}^{2}\right)$, gender, race

Type:

Cadaveric

Comorbidities:

Smoking history, diabetes, hypertension, creatinine, clinical infection

Cause of death:

Anoxia, head trauma, stroke

Serology:

ABO compatibility, cytomegalovirus antibodies

\section{Surgical}

Double LTx, ischemic time, year of transplantation

$F E V_{1}$, Forced expiratory volume in 1 second; $F V C$, forced vital capacity; ECMO, extracorporeal membrane oxygenation; LTx, lung transplantation. 
TABLE E1. Characteristics of respiratory-supported recipients who were not propensity matched $(n=22)$

\begin{tabular}{|c|c|c|}
\hline Characteristic & $\mathbf{n}^{*}$ & No. $(\%)$ or Mean \pm SD \\
\hline Age (mo) & 22 & $12 / 12 / 29 \dagger$ \\
\hline Female & 22 & $12(55)$ \\
\hline African-American & 22 & $3(14)$ \\
\hline Height $(\mathrm{cm})$ & 22 & $69 \pm 24$ \\
\hline Weight (kg) & 22 & $8.3 \pm 9.1$ \\
\hline Body surface area $\left(\mathrm{m}^{2}\right)$ & 22 & $0.40 \pm 0.25$ \\
\hline Body mass index $\left(\mathrm{kg} / \mathrm{m}^{2}\right)$ & 22 & $16 \pm 4.5$ \\
\hline \multicolumn{3}{|l|}{ Diagnosis } \\
\hline Idiopathic pulmonary fibrosis & 22 & $2(9.1)$ \\
\hline Primary arterial hypertension & 22 & $3(14)$ \\
\hline Other $\ddagger$ & 22 & $17(77)$ \\
\hline Oxygen requirement at rest $\left(\mathrm{L} / \mathrm{min}^{1}\right)$ & 19 & $9.8 \pm 2.5$ \\
\hline Diabetes & 21 & $1(4.8)$ \\
\hline Serum creatinine $\left(\mathrm{mg} / \mathrm{dL}^{1}\right)$ & 21 & $0.39 \pm 0.33$ \\
\hline
\end{tabular}

